\title{
Article \\ Volatile Organic Compounds in Breads Prepared with Different Sourdoughs
}

\author{
Lucia De Luca, Alessandra Aiello (D), Fabiana Pizzolongo*(D), Giuseppe Blaiotta (D), Maria Aponte \\ and Raffaele Romano (D)
}

Citation: De Luca, L.; Aiello, A.; Pizzolongo, F.; Blaiotta, G.; Aponte, M.; Romano, R. Volatile Organic Compounds in Breads Prepared with Different Sourdoughs. Appl. Sci. 2021, 11, 1330. https://doi.org/10.3390/ app11031330

Academic Editor: Lorenzo Favaro Received: 27 December 2020

Accepted: 29 January 2021

Published: 2 February 2021

Publisher's Note: MDPI stays neutral with regard to jurisdictional claims in published maps and institutional affiliations.

Copyright: (c) 2021 by the authors. Licensee MDPI, Basel, Switzerland. This article is an open access article distributed under the terms and conditions of the Creative Commons Attribution (CC BY) license (https:// creativecommons.org/licenses/by/ $4.0 /$ )
Department of Agricultural Sciences, University of Naples Federico II, via Università 100, 80055 Portici, Italy; lucia.deluca@unina.it (L.D.L.); alessandra.aiello@unina.it (A.A.); giuseppe.blaiotta@unina.it (G.B.); maria.aponte@unina.it (M.A.); rafroman@unina.it (R.R.)

* Correspondence: fabiana.pizzolongo@unina.it

Abstract: Sourdough is an old example of a natural starter composed of a mixture of flour, water, and metabolites and is produced by naturally occurring lactic acid bacteria and yeasts that influence bread aroma. In this work, four types of sourdough were used to prepare bread: one sourdough with yeast beer and three with bacteria and yeasts. The physicochemical parameters $(\mathrm{pH}$, moisture, water activity, and organic acids) of the bread and sourdoughs were assessed. Lactic, acetic, and succinic acids were found in considerable amounts in sourdoughs and the corresponding breads. The fermentation quotient (molar ratio between lactic and acetic acid) ranged from 0.39 to 3.4 in sourdoughs. Lactic acid was prevalent in all types of bread and showed the highest value in bread made from sourdough with a 1.5 bacteria/yeast ratio $(8722.24 \mathrm{mg} / \mathrm{kg})$. Moreover, volatile organic compounds were identified in bread samples. Alcohols, aldehydes, and acetic acid were mainly found. The alcohol concentration ranged from 140.88 to $401.20 \mathrm{ng} / \mathrm{g}$. Aldehydes ranged from 185.01 to $454.95 \mathrm{ng} / \mathrm{g}$, and acetic acid ranged from 91.40 to $173.81 \mathrm{ng} / \mathrm{g}$. Bread prepared from sourdough with a 1.5 bacteria/yeast ratio showed a considerable amount of alcohols and acetic acid.

Keywords: bakery products; SPME-GC/MS; fermentation; organic acids; HPLC; aroma profile

\section{Introduction}

Bread is one of the most widely consumed foods in the world. The production of bread involves three important steps: dough mixing, dough fermentation, and baking. Fermentation is an important process, and sourdough is an important fermentation method based on spontaneous processes.

The sourdough microflora is characterized by lactic acid bacteria (LAB) and yeasts that have an important role in the fermentation of bread dough as well as increasing the aroma of bread and conferring the typical flavor. The concentrations of LAB and yeasts in sourdoughs are approximately $10^{8}-10^{9} \mathrm{CFU}$ (Colony-forming unit) / g and $10^{6}-10^{7} \mathrm{CFU} / \mathrm{g}$, respectively. The ratio between $\mathrm{LAB}$ and yeast is 100:1 [1], and the quality of sourdough is influenced by the type of starter culture, acidity, medium, and substrate of fermentation $[2,3]$.

Among LAB species, Lactobacillus sanfranciscensis, Lactobacillus plantarum, Lactobacillus brevis, Pediococcus pentosaceus, Lactobacillus paralimentarius, and Lactobacillus fermentum are predominant, while among yeasts, the most prevalent species are Candida humilis and Saccharomyces cerevisiae. Based on the technology applied, sourdough is subdivided into three types. Type I (traditional) sourdough is restarted using a part of a previous fermentation. This type of dough is stable and contains $L A B$ and yeasts. LAB influence the acidity of dough, while yeasts with $\mathrm{LAB}$ influence the flavor, presence of $\mathrm{CO}_{2}$, and texture of the final product and delay stalling [4-6]. Type II (industrial type) sourdough is prepared using selected strains to start fermentation. During type II sourdough production, baker's yeast is added to the sourdough at the end of the fermentation process [7]. Finally, type III 
sourdough can be dried. This type of sourdough is convenient for preserving authentic bread taste as a product of the bakery industry [2]. In addition, variations in the types of starter cultures can be used in the fermentation process. Additionally, the fermentation conditions (temperature, time, $\mathrm{pH}$ ) may differ significantly with the process applied [8].

The generation of volatiles in sourdoughs is clearly influenced by the activity of the $\mathrm{LAB}$ and yeasts, and factors influencing their activity determine the amounts of metabolites formed. Generally, LAB are mostly responsible for acidification, while both types of microbes are able to liberate aroma precursors, such as free amino acids, and their concentrations increase significantly during sourdough fermentation $[6,8,9]$. Sourdough is mainly used to improve the aroma of wheat bread.

During baking, the raw dough is converted into a brown-colored product. The ingredients used for the preparation of bread are important to develop the bread's aromatic profile. Different steps can influence the aromatic profile of bread, such as dough fermentation by yeasts and/or LAB, enzymatic activity, and thermal reaction developed during bread baking [10]. The flavor of bread crumb is influenced mainly by enzymatic reactions during dough fermentation, whereas the flavor of bread crust is more influenced by thermal reactions during the baking process, such as the nonenzymatic Maillard reactions and caramelization of sugars [11].

More than 300 identified volatile organic compounds belonging to different chemical classes, such as acids, aldehydes, ketones, alcohols, esters, and sulfide compounds, are produced during fermentation and cooking.

The use of sourdough $\mathrm{LAB}$ and yeasts increases the aromatic quality of bread; in fact, the use of LAB (homo- and heterofermentative) and yeasts influences the profile of volatile organic compounds [12]. Sourdoughs are characterized by high alcohol concentrations, aldehydes, ketones, esters, acids, and terpenes [13].

Furthermore, sourdough fermentation influences the rheological, sensory, and shelflife attributes of bakery products. Recently, the effects of sourdough fermentation on several functional/nutritional aspects of baked products were shown. Some aspects, such as the potential of a lower glycemic index to increase mineral bioavailability as well as decrease the gluten content, have been almost completely elucidated [14].

Therefore, the present work aimed to evaluate the influence of four different sourdoughs with different ratios of bacteria/yeasts prepared with different types of wheat flour on both volatile organic compounds and organic acid concentrations of bread.

\section{Materials and Methods}

\subsection{Chemicals}

Citric acid and orthophosphoric acid were obtained from Carlo Erba (Milan, Italy). Acetic acid, lactic acid, succinic acid, 2-methyl-3-heptanone, maltose, dextrose, fructose, yeast extract, Tween 80, tryptone, and $\mathrm{HCl}$-cysteine were purchased from Merck (Darmstadt, Germany). Deionized water was obtained from a Milli-Q water purification system (Millipore, Bedford, MA, USA).

\subsection{Sourdough Preparation}

Four types of sourdoughs were prepared by the addition of microbial cultures to a mix of water and flour (1:1): S1, S2, S3, and S4 (Table 1). Sourdoughs S1, S2, and S4 were prepared using wheat flour type 00 and Manitoba flour (4:1), while sourdough S3 was prepared with wheat flour type 00 and wheat flour type 0 (4:1). The sourdoughs (S1, S2, and S3) were made and propagated through a traditional protocol starting from mixtures with different amounts (CFU/g) of yeasts and Lactobacillus strains (1.5, 3.3, and 3.3 bacteria/yeast ratio, respectively), while $S 4$ was obtained without selected microbial cultures but with yeast beer (Saccharomyces cerevisiae) taken from a spontaneously fermented beer stored in oak barrique (Table 1). 
Table 1. Sourdough samples.

\begin{tabular}{ccc}
\hline Samples & Wheat Flour Used & Microbial Cultures \\
\hline S1 sourdough & Wheat flour 00 and Manitoba flour (4:1) & Bacteria/Yeast in 1.5 ratio (selected cultures) \\
S2 sourdough & Wheat flour 00 and Manitoba flour (4:1) & Bacteria/Yeast in 3.3 ratio (selected cultures) \\
S3 sourdough & Wheat flour 00 and wheat flour 0 (4:1) & Bacteria/Yeast in 3.3 ratio (selected cultures) \\
S4 sourdough & Wheat flour 00 and Manitoba flour (4:1) & Yeast beer (natural cultures) \\
\hline
\end{tabular}

The microbial cultures were isolated in liquid media SBDS1 (maltose $15 \mathrm{~g} / \mathrm{L}$; glucose $3 \mathrm{~g} / \mathrm{L}$, fructose $5 \mathrm{~g} / \mathrm{L}$; yeast extract $20 \mathrm{~g} / \mathrm{L}$; tween $800.3 \mathrm{~g} / \mathrm{L}$; tryptone $6 \mathrm{~g} / \mathrm{L}$; cysteine- $\mathrm{HCl}$ $0.5 \mathrm{~g} / \mathrm{L}$; vitamins $3.3 \mathrm{~mL} / \mathrm{L}$; agar $20 \mathrm{~g} / \mathrm{L}$ ) and centrifuged.

The microbes were added only in the first dough; subsequently, the acidic dough was refreshed every week with the addition of flour and water at a ratio of 1:1 [15] for 8 months (until sourdough stabilization). The 8-month refreshed sourdoughs were used to produce the bread and were subjected to microbiological characterization and chemical analysis $(\mathrm{pH}$, titratable acidity, and organic acid determination).

\subsection{Bread Preparation}

The pre-doughs were prepared with the addition of $100 \mathrm{~g}$ of sourdough (S1, S2, S3, and S4), $100 \mathrm{~g}$ of wheat flour 00 (Molino del Clitunno, Italy), and $50 \mathrm{~g}$ of water. Subsequently, the pre-dough was fermented for $16 \mathrm{~h}$ at $16^{\circ} \mathrm{C}$.

To prepare the dough, $125 \mathrm{~g}$ of pre-dough was added to $500 \mathrm{~g}$ of wheat flour $00,275 \mathrm{~g}$ of water, and $12.5 \mathrm{~g}$ of salt. All ingredients were mixed for $20 \mathrm{~min}$ with a spiral mixer (Mecnosud series M). The dough was molded manually, left to fermentate for $4 \mathrm{~h}$ at $28^{\circ} \mathrm{C}$, and baked in an electric oven (Bake off Italiana srl, Italy) at $220^{\circ} \mathrm{C}$ for $50 \mathrm{~min}$ to obtain loaves of approximately $500 \mathrm{~g}$.

An internal slice comprising crust and crumb of approximately $50 \mathrm{~g}$ from each loaf was homogenized to obtain a representative sample and submitted to moisture, water activity, and $\mathrm{pH}$ analysis. The bread samples were stored at $-20^{\circ} \mathrm{C}$ until organic acid and volatile organic compounds determination.

\subsection{Sourdough Microbiological Characterization}

Twenty grams of each sourdough was homogenized with $180 \mathrm{~mL}$ of sterile peptone water solution and diluted. For microbiological counts, the dilutions were enumerated on SDBS1 substrate (maltose $15 \mathrm{~g} / \mathrm{L}$; glucose $3 \mathrm{~g} / \mathrm{L}$, fructose $5 \mathrm{~g} / \mathrm{L}$; yeast extract $20 \mathrm{~g} / \mathrm{L}$; tween $800.3 \mathrm{~g} / \mathrm{L}$; tryptone $6 \mathrm{~g} / \mathrm{L}$; cysteine- $\mathrm{HCl} 0.5 \mathrm{~g} / \mathrm{L}$; vitamins $3.3 \mathrm{~mL} / \mathrm{L}$; agar $20 \mathrm{~g} / \mathrm{L}$ ) with the addition of chloramphenicol for yeast selection and cycloheximide for bacterial selection. The plates were incubated for $48 \mathrm{~h}$ at $28^{\circ} \mathrm{C}$.

\subsection{Physicochemical Analysis}

The $\mathrm{pH}$ values of sourdough and dough bread were measured after calibration with a basic $\mathrm{pH}$ meter 20 (Crison Instruments, Barcelona, Spain) following the procedure of Park et al. [16].

The titratable acidity (TA) was determined in sourdoughs using the method described by Spicher and Stephan [1]. Briefly, $100 \mathrm{~mL}$ of acetone/water (5:95 $\mathrm{v} / \mathrm{v})$ was added to $10 \mathrm{~g}$ of sourdough and homogenized. Subsequently, 2 drops of phenolphthalein were added, and the initial $\mathrm{pH}$ was measured. The $\mathrm{pH}$ was then titrated using a $0.1 \mathrm{~N} \mathrm{NaOH}$ solution until reaching a $\mathrm{pH}$ of 8.5 (corresponding to the change in phenolphthalein to pink). The total titratable acidity was expressed as $\mathrm{mL}$ of $\mathrm{NaOH} / 10 \mathrm{~g}$ of sample.

Moisture content was evaluated in bread by the gravimetric method following the procedure based on the official method G.U 189/1967 [17]. The samples were oven-dried at $105^{\circ} \mathrm{C}$ for $12 \mathrm{~h}$ and accurately weighed until a constant weight was reached. Three measurements were performed for each sample. The moisture content was expressed as $\mathrm{g} / 100 \mathrm{~g}$ of bread. 
The water activity $\left(\mathrm{a}_{\mathrm{w}}\right)$ was measured in bread using an Aqua Lab instrument (METER Group, Inc., Pullman, WA, USA). Three measurements were performed for each sample.

\subsection{Determination of Organic Acids in Sourdough and Bread}

The extraction of organic acids (lactic, succinic, acetic, and malic acids) in sourdoughs was performed following the method of Mueen-ud-Din et al. [18], with modifications. Briefly, the sourdough was diluted (1:10) with water and centrifuged at $8000 \times g$ for 15 min. The supernatant was filtered through a $0.22 \mu \mathrm{m}$ membrane filter and injected in highpressure liquid chromatography (HPLC).

The extraction of organic acids from bread was carried out according to the method of Ua Arak et al. [19] with modifications. Briefly, $10 \mathrm{~g}$ of sample was added to $100 \mathrm{~mL}$ of ultrapure water, and the mixture was homogenized and centrifuged at $8000 \times g$ for $15 \mathrm{~min}$. The supernatant was filtered through a $0.22 \mu \mathrm{m}$ membrane filter, diluted with $3 \mathrm{~mL}$ of water, and injected into HPLC.

HPLC analysis was carried out with an Agilent 1100 series system equipped with a Spherisorb S5 ODS2 column $(5 \mu \mathrm{m}, 4.6 \times 250 \mathrm{~mm})$ and a photo diode array detector. The mobile phase was composed of ultrapure water acidified with phosphoric acid at $\mathrm{pH} 2.1$ under isocratic conditions at $25^{\circ} \mathrm{C}$. The flow was set at $0.6 \mathrm{~mL} / \mathrm{min}$. The wavelength of the detector was set at $210 \mathrm{~nm}$. The organic acid concentration was determined with a calibration curve constructed with organic acid standards (acetic acid, lactic acid, citric acid, and succinic acid).

The range of linearity and the square of the correlation coefficient $\left(\mathrm{R}^{2}\right)$ for lactic acid were 30-2000 ppm and 0.99, respectively, while the range of linearity of acetic, citric, and succinic acid was 10-100 ppm, and the correlation coefficient $\left(R^{2}\right)$ was $0.99,1$, and 0.99 , respectively.

The results were expressed as mg of organic acid $/ \mathrm{kg}$ of sample.

\subsection{Volatile Organic Compounds of Bread}

The extraction of the volatile organic compounds (VOCs) of bread was performed using solid-phase microextraction-gas chromatography-mass spectrometry (SPME-GC/MS) as reported by Aponte et al. [20], with modifications. The VOCs were extracted by mixing $2 \mathrm{~g}$ of bread with $2 \mathrm{~mL}$ of water and $5 \mu \mathrm{L}$ of 2-methyl-3-heptanone as an internal standard $(41.78 \mathrm{mg} / \mathrm{L})$ inserted into a $20 \mathrm{~mL}$ vial.

After the vial was sealed, the sample was stirred with a magnetic stirrer at $50{ }^{\circ} \mathrm{C}$, and a divinylbenzene/carboxen/polydimethylsiloxane (DVB/CAR/PDMS) fiber was introduced into the vial for $30 \mathrm{~min}$. Then, the fiber was introduced into the GC injector, where thermal desorption of the analytes was performed at $250{ }^{\circ} \mathrm{C}$ for $10 \mathrm{~min}$.

A GC system 6890N equipped with a 5973 mass detector (Agilent Technologies, Palo Alto, CA, USA) was used. The VOCs were separated on an HP-5 MS capillary column $(30 \mathrm{~m} \times 0.25 \mathrm{~mm}$ ID $\times 0.25 \mu \mathrm{m})$ of $5 \%$ diphenyl 195\% dimethylpolysiloxane (HP5 MS J\&W Scientific, Folson, CA, USA). The column oven temperature was held at $40^{\circ} \mathrm{C}$ for $2 \mathrm{~min}$ and increased from $40{ }^{\circ} \mathrm{C}$ to $160{ }^{\circ} \mathrm{C}$ at $6{ }^{\circ} \mathrm{C} / \mathrm{min}$ and from 160 to $210{ }^{\circ} \mathrm{C}$ at $10^{\circ} \mathrm{C} / \mathrm{min}$. The injection and ion source temperatures were 250 and $230{ }^{\circ} \mathrm{C}$, respectively. Helium was used as the carrier gas at a flow rate of $0.9 \mathrm{~mL} / \mathrm{min}$. The ionizing electron energy was $70 \mathrm{eV}$, and the mass range scanned was 33-300 amu in full-scan acquisition mode. The compounds were identified using the NIST (National Institute of Standards and Technology) Atomic Spectra Database version 2.0 and verified by retention indices.

The VOCs were calculated by the internal standard method and are expressed as $\mathrm{ng} / \mathrm{g}$ of sample.

\subsection{Statistical Analysis}

All experiments and determinations were performed in triplicate, and the reported results are the mean values ( \pm standard deviations) of the triplicate analysis. One-way analysis of variance (ANOVA), Tukey's multiple-range test ( $p \leq 0.05)$, and principal com- 
ponent analysis (PCA) were conducted on the data using XLSTAT software (Addinsoft, New York, NY, USA).

\section{Results}

\subsection{Microbiological and Physicochemical Analysis}

In Table 2, the microbiological composition and physicochemical results of sourdoughs after 8 months of stabilization are shown. The yeasts and bacteria were present in the highest amounts in S4 sourdough, with bacteria at a concentration of $6.55 \times 10^{8} \mathrm{CFU} / \mathrm{g}$ and yeasts at a concentration of $5.65 \times 10^{7} \mathrm{CFU} / \mathrm{g}$. Although $\mathrm{S} 4$ was prepared with only yeast beer, after 8 months of stabilization, bacteria were also found, indicating the growth of natural bacteria (Table 2). S3 and S2 prepared with the same bacteria/yeast ratio showed a different ratio after 8 months: S3 had a higher ratio than S2 (159.15 vs. 47.05). S3 sourdough was prepared with wheat flour type 0 and wheat flour type 00 at a ratio of 3:1, while S2 sourdough was prepared with wheat flour type 00 and Manitoba flour at a ratio of 80:20. The type of flour used could influence the sourdough composition [21].

Table 2. Microbiological characterization, $\mathrm{pH}$ value, titratable acidity of 8 months refreshed sourdoughs used to produce bread.

\begin{tabular}{|c|c|c|c|c|c|c|c|}
\hline Samples & Bacteria/Yeasts Ratio & Bacteria (CFU/g) & Yeasts (CFU/g) & Predominant Yeast Species & Predominant Bacteria Species & $\mathrm{pH}$ & $\begin{array}{l}\text { Titratable Acidity (mL } \\
\text { NaOH/10 g Sample) }\end{array}$ \\
\hline S1 sourdough & 12.75 & $3.25 \times 10^{8 c} \pm 0.77$ & $2.55 \times 10^{7 b} \pm 1.1$ & $\begin{array}{l}\text { S. cerevisiae } \\
\text { \& K. unispora }\end{array}$ & L. sanfranciscensis & $4.02^{c} \pm 0.01$ & $6.33^{c} \pm 0.01$ \\
\hline S2 sourdough & 47.05 & $4.00 \times 10^{8} \mathrm{~b} \pm 1.27$ & $8.50 \times 10^{6 c} \pm 1.27$ & S. cerevisiae & L. sanfranciscensis & $4.07 \mathrm{~b} \pm 0.01$ & $6.50^{b} \pm 0.01$ \\
\hline S3 sourdough & 159.15 & $5.65 \times 10^{8 \mathrm{a}, \mathrm{b}} \pm 0.35$ & $3.55 \times 10^{6 c} \pm 0.07$ & S. cerevisiae & L. sanfranciscensis & $4.22 \mathrm{a} \pm 0.01$ & $6.32^{c} \pm 0.03$ \\
\hline S4 sourdough & 11.59 & $6.55 \times 10^{8} \mathrm{a} \pm 0.21$ & $5.65 \times 10^{7} \mathrm{a} \pm 0.35$ & S. cerevisiae & L. sanfranciscensis & $3.87 \mathrm{~d} \pm 0.01$ & $7.32^{a} \pm 0.03$ \\
\hline
\end{tabular}

a-d: different letters in the same column indicate statistically significant difference $(p<0.05)$.

The species of bacteria found was Lactobacillus sanfranciscensis, while for yeast, Saccharomyces cerevisiae was found. Furthermore, in sourdough S1, the yeast Kazachstania unispora was also found.

The $\mathrm{pH}$ value ranged between 3.87 in S4 and 4.22 in $\mathrm{S} 3$. The $\mathrm{pH}$ of a stabilized sourdough is influenced by the nature of the process and starter culture used, and generally, it ranges from 3.5 to 4.3 in wheat sourdoughs [2].

The TA ranged between $6.32 \mathrm{~mL}$ of $\mathrm{NaOH} / 10 \mathrm{~g}$ of sample in $\mathrm{S} 3$ to $7.32 \mathrm{~mL}$ of $\mathrm{NaOH} / 10 \mathrm{~g}$ of sample in S4. The values were in accordance with Mueen-ud-Din et al. [18], who showed a value that ranged between 3.5 and $9.7 \mathrm{~mL}$ of NaOH/10 g of the sample depending on the cultures used to prepare sourdoughs.

The trend of the $\mathrm{pH}$ value of dough bread during fermentation is shown in Figure 1. At the beginning of fermentation, the $\mathrm{pH}$ was in the range of 5.56-5.63, while at the end of fermentation, it ranged between 4.22 in $\mathrm{S} 1$ and 4.30 in S4. The $\mathrm{pH}$ value at the end of fermentation was over 4.1, according to Torrieri et al. [22], who showed a $\mathrm{pH}$ value that ranged between 4.73 and 5.03 depending on the concentration of sourdough used for the preparation of bread. 


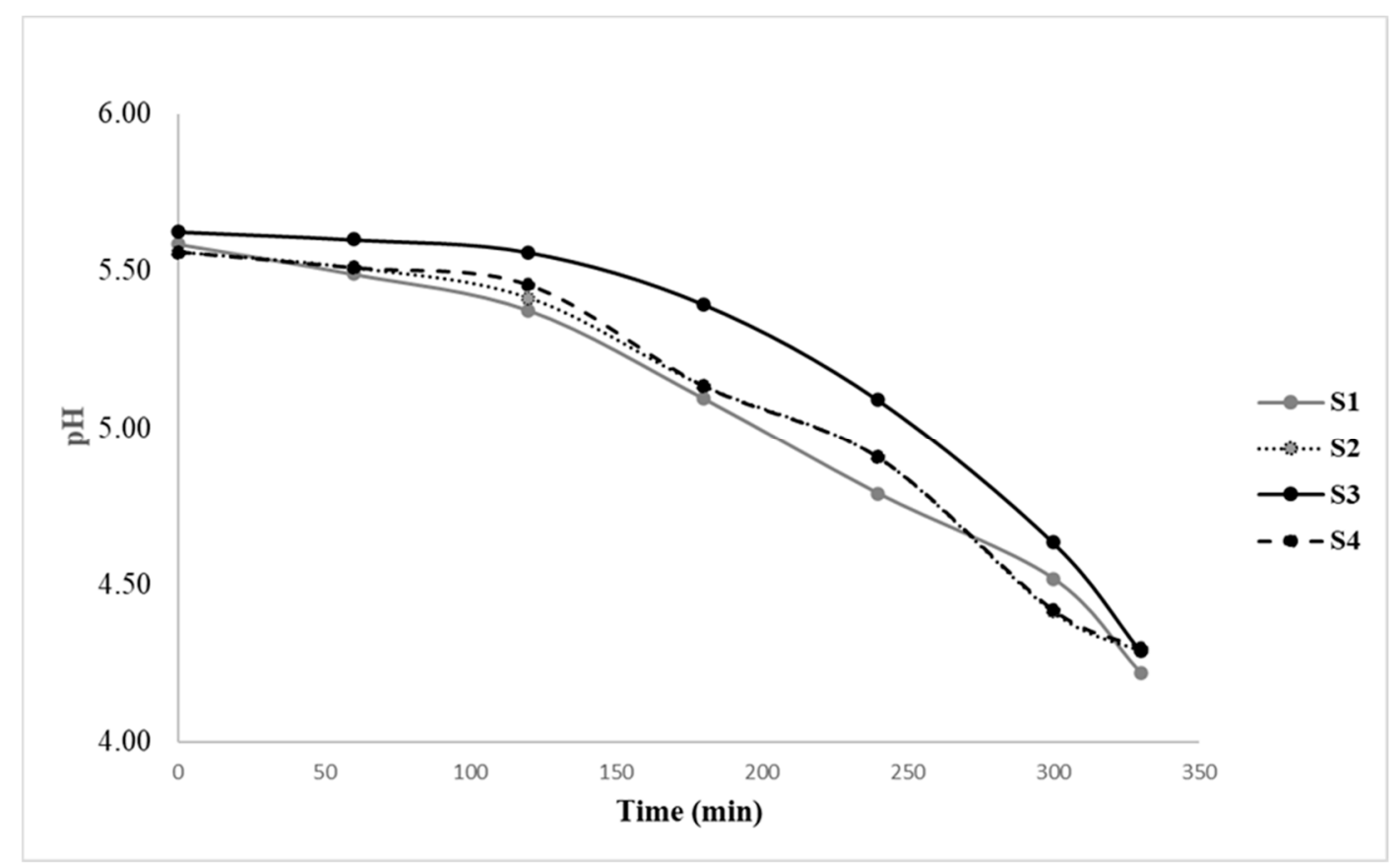

Figure 1. $\mathrm{pH}$ values of bread doughs obtained from different sourdoughs (S1, S2, S3, and S4) during fermentation at $28^{\circ} \mathrm{C}$.

The moisture and $\mathrm{a}_{\mathrm{w}}$ values of bread in Table 3 are shown, and a positive correlation between them was found. S1 and S4 showed the highest values of both moisture and $\mathrm{a}_{\mathrm{w}}$, while S3 showed the lowest value. The moisture content ranged between $22.99 \mathrm{~g} / 100 \mathrm{~g}$ in bread S3 and $28.20 \mathrm{~g} / 100 \mathrm{~g}$ in S1. According to G.U. 189/1967 [17], the moisture content does not exceed $34 \%$ in any bread samples. The moisture content was lower than the value reported by Scazzina et al. [23], which was $31 \mathrm{~g} / 100 \mathrm{~g}$ of bread, while the results were similar to those of Zolfaghar et al. [24], who reported a range between $27.23 \mathrm{~g} / 100 \mathrm{~g}$ and $29.99 \mathrm{~g} / 100 \mathrm{~g}$ in bread prepared with different leavening agents.

Table 3. Moisture (\%) and water activity $\left(\mathrm{a}_{\mathrm{w}}\right)$ of bread obtained from different sourdoughs (S1, S2, S3, and S4).

\begin{tabular}{ccc}
\hline Sample & Moisture & $\mathbf{a}_{\mathbf{w}}$ \\
\hline S1 bread & $28.20^{\mathrm{a}} \pm 0.22$ & $0.90^{\mathrm{a}} \pm 0.01$ \\
S2 bread & $25.26^{\mathrm{b}} \pm 0.43$ & $0.89^{\mathrm{a}} \pm 0.01$ \\
S3 bread & $22.99^{\mathrm{c}} \pm 0.84$ & $0.81^{\mathrm{b}} \pm 0.01$ \\
S4 bread & $27.33^{\mathrm{a}} \pm 0.78$ & $0.90^{\mathrm{a}} \pm 0.01$ \\
\hline
\end{tabular}

a-c: different letters in the same column indicate statistically significant difference $(p<0.05)$.

The $\mathrm{a}_{\mathrm{w}}$ value in bread ranged between 0.81 in S3 and 0.90 in S1 and S4. All $\mathrm{a}_{\mathrm{w}}$ values were similar to bread analyzed by Mohd Roby [25], who showed a range between 0.88 and 0.90 depending on the type of starter added to prepare the bread. Water activity is the ratio of vapor pressures to water in a food system at a certain temperature and is important to define product quality and safety regarding microbial growth, chemical and biochemical reaction rates, and physical characteristics [26]. High values of $a_{w}$ promote mold growth, and the most common way to decrease the mold growth is to lower $\mathrm{a}_{\mathrm{w}}$ to a minimum value. The critical $a_{w}$ for mold growth depends on mold species $\backslash$ substrate and temperature. Furthermore, $a_{w}$ influences the firmness of bread. In fact, low $a_{w}$ values are correlated with an increase in the firmness of bread [26,27].

\subsection{Organic Acid in Sourdough and Bread}

The concentration of organic acids in sourdoughs is shown in Table 4a. Lactic acid ranged from 685.31 to $1895.84 \mathrm{mg} / \mathrm{kg}$ in S2 and S1, representing 27 and $81 \%$ of the total 
organic acids, respectively. Acetic acid ranged from 370.86 to $1164.61 \mathrm{mg} / \mathrm{kg}$ in S1 and S2, representing 16 and $47 \%$ of the total organic acids, respectively. Succinic acid ranged from 80.37 to $1110.37 \mathrm{mg} / \mathrm{kg}$ in S1 and S4, representing 3 and $29 \%$ of the total organic acids, respectively. The total organic concentrations of sourdoughs (lactic, acetic, succinic, and citric acid) ranged from 2347.07 to $3807.05 \mathrm{mg} / \mathrm{kg}$ in S1 and S4, respectively.

Table 4. Organic acid concentration $(\mathrm{mg} / \mathrm{kg})$ and fermentation quotient (FQ) in sourdough (a) and corresponding bread (b).

(a)

\begin{tabular}{|c|c|c|c|c|c|}
\hline Sample & Lactic Acid & Acetic Acid & Succinic Acid & Citric Acid & FQ \\
\hline S1 sourdough & $1895.84^{\mathrm{a}} \pm 1.15$ & $370.86^{c} \pm 0.64$ & $80.37^{\mathrm{d}} \pm 0.00$ & $<5.00$ & $3.41^{\mathrm{a}} \pm 0.30$ \\
\hline S2 sourdough & $685.31^{b} \pm 0.21$ & $1164.61^{\mathrm{a}} \pm 3.25$ & $641.62^{b} \pm 2.05$ & $<5.00$ & $0.39^{c} \pm 0.04$ \\
\hline S3 sourdough & $1786.82^{\mathrm{a}} \pm 2.06$ & $674.61^{b} \pm 2.26$ & $362.87^{\mathrm{c}} \pm 0.99$ & $<5.00$ & $1.76^{b} \pm 0.14$ \\
\hline S4 sourdough & $1888.32^{a} \pm 6.22$ & $808.36^{b} \pm 0.49$ & $1110.37^{a} \pm 0.85$ & $<5.00$ & $1.56^{\mathrm{b}} \pm 0.23$ \\
\hline \multicolumn{6}{|c|}{ (b) } \\
\hline Sample & Lactic Acid & Acetic Acid & Succinic Acid & Citric Acid & FQ \\
\hline S1 bread & $8722.24^{\mathrm{a}} \pm 4.45$ & $774.23^{b} \pm 2.12$ & $5243.24^{\mathrm{a}} \pm 6.72$ & $<5.00$ & $7.88^{b} \pm 2.94$ \\
\hline S2 bread & $5607.30^{b} \pm 8.27$ & $254.21^{\mathrm{c}} \pm 0.42$ & $1035.74^{b} \pm 2.12$ & $1402.40^{\mathrm{a}} \pm 2.83$ & $14.70^{\mathrm{a}} \pm 2.77$ \\
\hline S3 bread & $5322.24^{b} \pm 3.75$ & $239.22^{\mathrm{c}} \pm 0.42$ & $980.74^{b} \pm 6.22$ & $1417.43^{a} \pm 2.69$ & $14.80^{\mathrm{a}} \pm 3.48$ \\
\hline S4 bread & $4874.74^{b} \pm 3.53$ & $1234.20^{\mathrm{a}} \pm 0.71$ & $1138.24^{b} \pm 2.05$ & $<5.00$ & $2.63^{c} \pm 0.26$ \\
\hline
\end{tabular}

In (a) a-d: different letters in the same column indicate statistically significative difference $(p<0.05)$. In (b) a-c: different letters in the same column indicate statistically significative difference $(p<0.05)$.

Furthermore, the fermentation quotient was calculated as the molar ratio between lactic acid and acetic acid, and it ranged between 0.39 in S2 and 3.41 in S1 (Table 4a), indicating that this latter has to be considered the best sourdough. This value, in fact, influences the flavor of leavened baked products, such as bread $[28,29]$. A fermentation quotient (FQ) of up to 3.2 is characteristic of lactic fermentation [30], and it has a considerable effect on the sensory characteristics and shelf life of breads [31]. Mamhoud et al. [32] showed an FQ that ranged between 3.12 and 4.67 in dough bread prepared with sourdoughs, while Spicher and Stephen [33] recommended an FQ value in the range of 1.5 to 4 to positively affect the aroma profile and the structure of the final products. FQ depends on sourdough microbial composition and its activities. The ratio between homo- and heterofermentative $\mathrm{LAB}$ is most likely involved in the FQ variation, but yeast activities may also influence the FQ. In this way, yeasts are known to have an impact on fructose liberation in sourdough through invertase activity, which, in turn, will produce acetic acid by LAB and, therefore, trigger a decrease in the FQ value [34].

The presence of acetic acid in sourdough is positive because it improves the sensory properties and possesses antiripeness and antimold activities [35]. Anyway, acetic acid at the normal sourdough $\mathrm{pH}$ (3.7-4.0) is mainly at the undissociated lipophilic and membranediffusible form, and combined with the ethanol, may have a detrimental effect on yeast growth [36,37].

The concentration of organic acids in bread is shown in Table $4 \mathrm{~b}$.

The highest value of lactic acid $(8722.24 \mathrm{mg} / \mathrm{kg})$ was found in S1 bread made from sourdough with the highest FQ of 3.41. The concentration range of lactic acid was from $4874.74 \mathrm{mg} / \mathrm{kg}$ in S4 (67\% of total organic acid) to $8722.24 \mathrm{mg} / \mathrm{kg}$ in S1 (59\% of total organic acids). These values are higher than those reported by Gobbetti et al. [28], who found lactic acid concentrations ranging from 3100 to $4500 \mathrm{mg} / \mathrm{kg}$. Hadaegh et al. [38] reported that the lactic acid concentration ranged from $308.1 \mathrm{mg} / \mathrm{kg}$ to $3301.2 \mathrm{mg} / \mathrm{kg}$ in toast bread prepared with different lactic acid bacterial sourdoughs. The lactic acid production is favorable to a more elastic gluten structure [39]. Therefore, $\mathrm{S} 1$ bread has to be considered the best sample.

The concentration of acetic acid ranged from $239.22 \mathrm{mg} / \mathrm{kg}$ in S3 to $1234.20 \mathrm{mg} / \mathrm{kg}$ in S4. These values are higher than those reported by Gobbetti et al. [28], who found acetic acid concentrations ranging from 180 to $600 \mathrm{mg} / \mathrm{kg}$ in bread prepared with different 
sourdough starters, while Hadaegh et al. [38] reported the concentration of acetic acid in the range of 2.72 to $47.54 \mathrm{mg} / \mathrm{kg}$ in toast bread prepared with different lactic acid bacterial sourdoughs.

The concentration of succinic acid ranged from $980.74 \mathrm{mg} / \mathrm{kg}$ in S3 (19\% of total organic acids) to $5243.24 \mathrm{mg} / \mathrm{kg}$ in S1 (51\% of total organic acids).

Finally, citric acid was detected only in S2 with a concentration of $1402.40 \mathrm{mg} / \mathrm{kg}$ (27\% of total organic acids) and in S3 with a concentration of $1417.43 \mathrm{mg} / \mathrm{kg}(26 \%$ of total organic acids). The content of total organic acids (lactic, acetic, succinic, and citric acids) ranged from 7247.18 to $14,739.71 \mathrm{mg} / \mathrm{kg}$ in S4 and S1 bread due to the difference in bacterial and yeast composition. The difference among results could derive from different ingredients in the sourdough composition. During fermentation, biochemical changes occur in the carbohydrate and protein of the flour due to the action of microbial and indigenous enzymes [40]. The ratio of bacteria and yeasts could also influence the FQ, which ranged from 2.63 to 14.80 in S4 bread and S3 bread, respectively (Table $4 \mathrm{~b}$ ).

\subsection{Volatile Organic Compounds of Bread}

In Table 5, the volatile organic compounds (VOCs) of bread prepared with different sourdoughs are shown. Alcohol, aldehydes, and acetic acid were the prevalent VOCs $(>100 \mathrm{ng} / \mathrm{g})$ found in all samples.

The total alcohol concentration ranged between $140.88 \mathrm{ng} / \mathrm{g}$ in S2 (25.34\% of VOCs) and $401.20 \mathrm{ng} / \mathrm{g}$ (37.32\% of VOCs) in S3. The alcohols present in bread were ethanol, 3-methyl-1-butanol, 2-methyl-1-butanol, 1-pentanol, 1-hexanol, 2-phenylethanol, and 2ethyl-1-hexanol.

The ethanol concentration ranged between $58.45 \mathrm{ng} / \mathrm{g}$ in S2 and $202.73 \mathrm{ng} / \mathrm{g}$ in S1, and alcohol was present at the highest concentration in all types of bread. Plessas et al. [41] showed a concentration that ranged between $140 \mathrm{ng} / \mathrm{g}$ and $4970 \mathrm{ng} / \mathrm{g}$, depending on the day of bread storage. This compound is derived from the metabolism of Saccharomyces cerevisiae, which is able to transform fermentable glucides in ethanol that evaporates during baking. The remaining part of ethanol can participate in secondary fermentation reactions, such as glycolysis of pyruvic acid, which leads to short-chain alcohols, short-chain fatty acids, esters, and carbonyl compounds [11].

Damiani et al. [12] showed that the ethanol content increased in sourdoughs supplemented with yeast. Ethanol is produced by LAB at a higher rate by heterofermentative species than homofermentative species in rye sourdoughs [42], and ethanol influences bread flavor with an odor described as strong, alcoholic, ethereal, and medicinal with a perception threshold in water of $100,000 \mathrm{ppb}$ [3].

The concentration of 3-methyl-1-butanol ranged between $30.24 \mathrm{ng} / \mathrm{g}$ in $\mathrm{S} 2$ and $97.46 \mathrm{ng} / \mathrm{g}$ in S3, a concentration lower than that reported by Birch et al. [43] at $6313 \mathrm{ng} / \mathrm{g}$ and $8768 \mathrm{ng} / \mathrm{g}$ depending on the commercial baker's yeast used to prepare bread. This compound is characterized by an odor described as banana, fruity, and almonds, and its odor threshold ranges between 250 and $300 \mathrm{ppb}$ in water [3]. Its concentration increases in sourdoughs supplemented with yeasts [8].

The concentration of 2-methyl-1-butanol ranged between $3.43 \mathrm{ng} / \mathrm{g}$ in S2 and $13.30 \mathrm{ng} / \mathrm{g}$ in S3, and the amounts of 2- and 3-methyl-1-butanol increased in sourdoughs with added yeast [8]. The formation of 3-methyl-1-butanol and 2-methyl-1-butanol could be derived during fermentation from flour amino acids (leucine and isoleucine, respectively) via the Ehrlich pathway in yeast cells [44].

The concentration of 2-phenylethanol ranged between $4.26 \mathrm{ng} / \mathrm{g}$ in S2 and $18.96 \mathrm{ng} / \mathrm{g}$ in S3, while Birch et al. [43] showed a concentration that ranged between 32 and $178 \mathrm{ng} / \mathrm{g}$ in breads prepared with different types of commercial yeasts. This compound gives the odor of flowers and rose [45], but the perception threshold in water was in the range of 750 to $1100 \mathrm{ppb}$ [3]. Furthermore, it was reported that it was positively correlated with the flavor of wheat crumb [46], and it could be derived from the fermentation of phenylalanine 
via the Ehrlich pathway in yeast cells [44]. Prolonged dough fermentation and the presence of Saccharomyces cerevisiae increase the concentration of 2-phenylethanol [47].

The concentration of hexanol ranged between 33.60 in S2 and $65.72 \mathrm{ng} / \mathrm{g}$ in S3. Birch et al. [48] showed a concentration that ranged between $42.5 \mathrm{ng} / \mathrm{g}$ and $53.4 \mathrm{ng} / \mathrm{g}$ in wheat bread crumb depending on the quantity of yeast added and fermentation temperature, while Birch et al. [43] showed a range between 360 and $589 \mathrm{ng} / \mathrm{g}$ depending on the commercial bakery yeast used. Apart from ethanol, 1-hexanol was the dominant alcohol in all sourdough breads. Hansen and Schieberle [8] showed that this compound was present in sourdough prepared both with starter cultures and starter cultures and sourdough yeasts. This compound influences the odors of ethereal, oil, alcohol, green, fruity, sweet, woody, and floral compounds. It originates from fermentative reactions and/or lipid oxidation, and its odor perception threshold in water is in the range of $2500 \mathrm{ppb}[3,48]$. Furthermore, Kaseleht et al. [42] showed that hexanol was produced more by heterofermentative than homofermentative bacteria in the dough.

Pentanol ranged between $6.17 \mathrm{ng} / \mathrm{g}$ in S2 and $14.48 \mathrm{ng} / \mathrm{g}$ in S3. Birch et al. [48] showed a range of concentrations of 19.6 to $24 \mathrm{ng} / \mathrm{g}$ in bread crumb depending on temperature fermentation and the quantity of yeast added to prepare the bread, while Birch et al. [43] showed a range of concentrations between 78 and $129 \mathrm{ng} / \mathrm{g}$ depending on the commercial bakery yeast used. This compound influences the odors of oil, sweet, balsamine, and chemical mint, and the perception threshold in water is $4000 \mathrm{ppb}$, a very high concentration [3,49]. It originates both by fermentative reactions and lipid oxidation [3,48], and it is present in the crust and crumb of bread [50]. Finally, the 2-ethyl-1-hexanol concentration ranged between 4.73 in S2 and $5.81 \mathrm{ng} / \mathrm{g}$ in S4, and the concentration ranged between $4.52 \mathrm{ng} / \mathrm{g}$ and $8.89 \mathrm{ng} / \mathrm{g}$ in bread crumb depending on the yeast quantity and temperature of fermentation [48] or between 9 and $27 \mathrm{ng} / \mathrm{g}$ depending on the commercial bakery yeast used [43]. This compound influences the odor of green/vegetables [11,47,51], and it was found in the crust and crumb bread [50]

The aldehydes ranged between $185.01 \mathrm{ng} / \mathrm{g}$ (33.29\% of total VOCs) in S2 and $454.95 \mathrm{ng} / \mathrm{g}$ (42.38\% of total VOCs) in S4. The identified aldehydes were 2-methylpropanal, 3-methylbutanal, 2-methylbutanal, hexanal, 3-furfural, heptanal, benzaldehyde, octanal, benzenacetaldehyde, and nonanal.

2-Methylpropanal ranged between 2.33 in S3 and $12.78 \mathrm{ng} / \mathrm{g}$ in S4, while the 3methylbutanal concentration ranged between 23.24 in S1 and $110.69 \mathrm{ng} / \mathrm{g}$ in S4. Birch et al. [43] showed a concentration that ranged between 11 and $47 \mathrm{ng} / \mathrm{g}$ in the crumb of bread prepared with different types of commercial yeasts, while Birch et al. [48] showed a concentration that ranged between 5 and $10.8 \mathrm{ng} / \mathrm{g}$, a concentration that depends on the fermentation temperature of the dough.

The 2-methylbutanal concentration ranged between 9.13 in S2 and $29.37 \mathrm{ng} / \mathrm{g}$ in S4. Jensen et al. [52] showed a concentration that ranged between 1 and $5 \mathrm{ng} / \mathrm{g}$, and this compound was found in the crumb and crust [53].

2-Methylpropanal, 2-methylbutanal and 3-methylbutanal are Strecker aldehydes derived by amino acid conversion by yeast; in particular, 2-methylpropanal derives from valine, 2-methylbutanal from isoleucine, and 3-methylbutanal from leucin. These aldehydes are characterized by a malty and fruity odor with a very low odor threshold in water that ranges between 0.1 and $2.3 \mathrm{ppb}[3,49,52]$.

The concentration of hexanal ranged between $59.59 \mathrm{ng} / \mathrm{g}$ in S2 and $103.69 \mathrm{ng} / \mathrm{g}$ in S4. A previous report indicated a concentration that ranged between $222 \mathrm{ng} / \mathrm{g}$ and $393 \mathrm{ng} / \mathrm{g}$ in the crumb of bread prepared with different commercial yeasts or $11.8 \mathrm{ng} / \mathrm{g}$ to $20.1 \mathrm{ng} / \mathrm{g}$ in bread prepared with different quantities of Saccharomyces cerevisiae and at different fermentation temperatures [43,48], while Jensen et al. [52] showed a concentration that ranged between $13 \mathrm{ng} / \mathrm{g}$ and $26 \mathrm{ng} / \mathrm{g}$ depending on the storage time of bread. This compound is present in the crust and crumb [50,53], and it influences fresh, green, fatty, aldehydic, grass, leafy, fruity, and sweaty odors [3,11,49], with a measured odor threshold in water of $4.5-5 \mathrm{ppb}[3,47,48]$. This aldehyde is derived from lipid oxidation $[44,48,52]$ 
and the fermentative metabolism of microbes [48]. Lipid oxidation compounds are often characterized as being off-flavor; therefore, the high level of hexanal in fermented bread might result in a lower acceptance of bread [48]. Furthermore, its presence in sourdough and bread was reported [3,52].

The furfural concentration ranged between $16.73 \mathrm{ng} / \mathrm{g}$ in S2 and $94.66 \mathrm{ng} / \mathrm{g}$ in S4. Plessas et al. [41] showed a concentration that ranged between 20 and $190 \mathrm{ng} / \mathrm{g}$ depending on the concentration and composition of sourdough used to prepare the bread. This molecule gives burnt, sweet, woody, almond, bread, and rancid odors to bread, and its odor threshold in water is approximately 3000-23,000 ppb [3,48]. It is formed during heating, during which, two main types of reactions were found: caramelization and the nonenzymatic Maillard reaction. In particular, furfural is derived from Amadori compounds produced during the Maillard reaction [11,47]. Heptanal ranged between $7.59 \mathrm{ng} / \mathrm{g}$ in S2 and $20.34 \mathrm{ng} / \mathrm{g}$ in S4, and different studies showed a concentration that ranged between 41 and $77 \mathrm{ng} / \mathrm{g}$ depending on commercial yeast used to prepare the bread or a range between 15.3 and $40.4 \mathrm{ng} / \mathrm{g}$ in the crumb of bread prepared with different quantities of yeasts and with different temperatures of fermentation [43,48]. Finally, Jensen et al. [52] showed a concentration that ranged between 1 and $2 \mathrm{ng} / \mathrm{g}$ depending on the storage time of bread with an increase in this compound during storage, and it was derived from lipid oxidation and found in bread prepared with and without sourdough and in the crust and crumb of bread [47,48]. This compound influences green, rancid, aldehydic, fatty, and grass odors with a perception threshold of $3 \mathrm{ppb}$ in water [3]. Benzaldehyde ranged between $9.64 \mathrm{ng} / \mathrm{g}$ in S2 and $15.70 \mathrm{ng} / \mathrm{g}$ in S4. This concentration is in accordance with Jensen et al. [52], who showed a range of concentrations between 9 and $23 \mathrm{ng} / \mathrm{g}$ in bread at different times of storage. Furthermore, Birch et al. [48] showed a range between 23 and $56 \mathrm{ng} / \mathrm{g}$ in bread prepared with different commercial yeasts; in another work, they showed a concentration that ranged between 15 and $79.8 \mathrm{ng} / \mathrm{g}$ depending on the quantity of yeasts and the temperature of fermentation. This compound is derived from lipid oxidation and fermentative reactions and is present in bread prepared with and without sourdough in the crust and crumb of bread. It influences almond, sweet, and cherry odors with a perception threshold in water between 350-3500 ppb [3,48,50].

The benzenecetaldehyde concentration ranged between $12.20 \mathrm{ng} / \mathrm{g}$ in S2 and $29.10 \mathrm{in}$ S4. The result is in accordance with Birch et al. [43], who showed a range of concentrations between 24 and $141 \mathrm{ng} / \mathrm{g}$ depending on the commercial yeast used for bread preparation, while Birch et al. [48] showed a range of concentrations between 27.25 and $48.25 \mathrm{ng} / \mathrm{g}$ depending on the quantity of yeasts and the temperature of fermentation. This compound derives from the fermentation of the dough and the Maillard reaction during baking. Its odor is described as honey-like, and it might be an important aroma compound because of the relatively lower threshold perception in water (4 ppb); furthermore, it was identified in bread crust and crumb $[3,50]$.

The nonanal concentration ranged between $13.36 \mathrm{ng} / \mathrm{g}$ in S2 and $31.17 \mathrm{ng} / \mathrm{g}$ in S2. Birch et al. [48] and Birch et al. [43] showed a concentration range between 14.59 and $20.38 \mathrm{ng} / \mathrm{g}$ and 18 and $34 \mathrm{ng} / \mathrm{g}$, while Jensen et al. [52] showed a concentration of approximately $2 \mathrm{ng} / \mathrm{g}$. Finally, Plessas et al. [41] showed a nonanal concentration of $70 \mathrm{ng} / \mathrm{g}$ in bread made with $50 \%$ sourdough. This compound derives from fermentation and lipid oxidation; its odor is described as soapy, fruit, rose, citrus, and orange, and it has a very low perception threshold in water (1 ppb) [3,47].

Acetic acid was the prevalent organic acid found and ranged between $91.40 \mathrm{ng} / \mathrm{g}$ in S2 and $173.81 \mathrm{ng} / \mathrm{g}$ in S3. This acid is produced by Lactobacillus during fermentation by the heterofermentative pathway [3,11], and it can be produced in the fatty acid synthase pathway in yeast cells, with yeast malonyl coenzyme A (CoA) as the substrate for fatty acid synthase [44]. The content of acetic acid influences the aroma of bread obtained by sourdough $[42,54]$.

The heterocyclic compounds were also found in the range between $39.74 \mathrm{ng} / \mathrm{g}(7.15 \%$ of total VOCs) in S2 and $79.09 \mathrm{ng} / \mathrm{g}$ (7.36\% of total VOCs) in S4. The identified heterocyclic 
compounds were 2-pentylfuran and 2,3-dihydrofuran. The concentration of 2-pentylfuran ranged between $31.95 \mathrm{ng} / \mathrm{g}$ in S2 and $72.40 \mathrm{ng} / \mathrm{g}$ in S4. This value is higher than the range reported by Birch et al. [48], Birch et al. [43], and Jensen et al. [52], which showed concentrations of $6.93-18.5 \mathrm{ng} / \mathrm{g}, 8-15 \mathrm{ng} / \mathrm{g}$, and $1-3 \mathrm{ng} / \mathrm{g}$, respectively. This compound is derived from Lactobacillus fermentation from sourdoughs fermented with starter cultures and sourdough yeasts, and its odor characteristics are fruity, green, earthy, bean, and metallic $[2,3,8,47]$. It is also derived from the heterofermentative and homofermentative pathways in doughs [42]. Finally, 2-pentylfuran could form from trans-2-nonenal, a lipid oxidation product of linoleic acid, during baking [55]. The 2,3-dihydrofuran concentration ranged between $2.98 \mathrm{ng} / \mathrm{g}$ in $\mathrm{S} 1$ and $7.79 \mathrm{ng} / \mathrm{g}$ in S2. The presence of furan derived from the Maillard reaction, which resulted in a loss of bread sample water, and the amino acid to sugar ratio is important for the proportion of furanes present in the bread [47].

Finally, during the process of baking, alkanals, 2-alkenals, and 2,4-alkadienals were also found, according to Salin Ur-Rehman et al. [46].

In Figure 2, the PCA illustrates which families are characteristic of different breads. The F1 and F2 factors explain $95.59 \%$ of the total variability. In particular, the factor F1 explains $63.30 \%$. The main contribution to F1 comes from alcohols (25.94\%). Factor F2 explains $32.29 \%$ of the variability, with the main contribution from aldehydes $(49.18 \%)$ followed by heterocyclic compounds $(40.34 \%)$. The majority of molecules were found in breads S1 and S3, which showed the highest contents of alcohols, acids, alkanes, and other compounds.

Table 5. Volatile organic compounds (ng/g) in bread obtained from different sourdoughs (S1, S2, S3, and S4).

\begin{tabular}{|c|c|c|c|c|c|c|}
\hline $\begin{array}{l}\text { Retention } \\
\text { Index (min.) }\end{array}$ & Compound & S1 Bread & S2 Bread & S3 Bread & S4 Bread & Odor Descriptors \\
\hline & Alcohols & $367.33^{a} \pm 25.10$ & $140.88^{c} \pm 3.98$ & $401.20^{\mathrm{a}} \pm 1.70$ & $276.49^{b} \pm 15.45$ & \\
\hline 1.57 & Ethanol & $202.73^{a} \pm 26.34$ & $58.45^{c} \pm 0.86$ & $185.52^{b} \pm 1.68$ & $131.84^{\mathrm{b}} \pm 16.65$ & $\begin{array}{l}\text { Strong, alcoholic, } \\
\text { ethereal, medicinal [3] }\end{array}$ \\
\hline 3.25 & $\begin{array}{l}\text { 3-Methyl-1- } \\
\text { butanol }\end{array}$ & $84.45^{b} \pm 2.06$ & $30.24^{\mathrm{d}} \pm 1.68$ & $97.46^{\mathrm{a}} \pm 0.21$ & $52.25^{c} \pm 1.93$ & $\begin{array}{l}\text { Banana, fruity, } \\
\text { almonds [3] }\end{array}$ \\
\hline 3.34 & $\begin{array}{l}\text { 2-Methyl-1- } \\
\text { butanol }\end{array}$ & $8.05^{b} \pm 0.60$ & $3.43^{c} \pm 0.65$ & $13.30^{\mathrm{a}} \pm 0.68$ & $9.63^{b} \pm 0.81$ & Malty $[56,57]$ \\
\hline 3.81 & 1-Pentanol & $11.06^{\mathrm{b}} \pm 0.42$ & $6.17^{c} \pm 0.41$ & $14.48^{\mathrm{a}} \pm 0.01$ & $13.53^{\mathrm{a}} \pm 0.65$ & $\begin{array}{c}\text { Oil, sweet, balsamine, } \\
\text { chemical mint, fusel } \\
\text { like }[3,49]\end{array}$ \\
\hline 5.90 & 1-Hexanol & $47.23^{b, c} \pm 5.40$ & $33.60^{c} \pm 4.06$ & $65.72^{\mathrm{a}} \pm 1.40$ & $57.98^{\mathrm{a}, \mathrm{b}} \pm 1.13$ & $\begin{array}{c}\text { Ethereal, oil, alcohol, } \\
\text { green, fruity, sweet, } \\
\text { woody, floral } \\
\text { compounds }[3,48]\end{array}$ \\
\hline 12.12 & 2-Phenylethanol & $8.82^{b} \pm 0.58$ & $4.26^{c} \pm 0.03$ & $18.96^{\mathrm{a}} \pm 0.62$ & $5.45^{c} \pm 0.15$ & Flowers, rose [45] \\
\hline \multirow[t]{2}{*}{9.94} & 2-Ethyl-1-hexanol & $5.32^{\mathrm{a}} \pm 0.53$ & $4.73^{a} \pm 0.29$ & $5.76^{\mathrm{a}} \pm 0.36$ & $5.81^{\mathrm{a}} \pm 0.38$ & $\begin{array}{c}\text { Green/vegetables } \\
{[11,51]}\end{array}$ \\
\hline & Aldehydes & $231.63^{b} \pm 1.86$ & $185.01^{c} \pm 3.98$ & $253.51^{b} \pm 4.98$ & $454.95^{\mathrm{a}} \pm 5.15$ & \\
\hline 1.83 & $\begin{array}{c}2- \\
\text { Methylpropanal }\end{array}$ & $4.07^{\mathrm{b}} \pm 0.40$ & $3.53^{b} \pm 0.37$ & $2.33^{\mathrm{b}} \pm 0.40$ & $12.78^{a} \pm 1.92$ & Malty, fruity $[3,49,52]$ \\
\hline 2.39 & 3-Methylbutanal & $23.24^{\mathrm{b}} \pm 1.52$ & $35.43^{\mathrm{b}} \pm 1.61$ & $25.48^{\mathrm{b}} \pm 0.44$ & $110.69^{\mathrm{a}} \pm 5.91$ & Malty, fruity $[3,49,52]$ \\
\hline 2.47 & 2-Methyllbutanal & $13.57^{\mathrm{a}, \mathrm{b}} \pm 1.94$ & $9.13^{b} \pm 1.11$ & $12.64^{a, b} \pm 0.68$ & $29.37^{\mathrm{a}} \pm 8.30$ & Malty, fruity $[3,49,52]$ \\
\hline 4.40 & Hexanal & $78.72^{a, b} \pm 0.97$ & $59.59^{b} \pm 4.46$ & $97.33^{a} \pm 5.59$ & $103.69^{\mathrm{a}} \pm 16.53$ & $\begin{array}{c}\text { Fresh, green, fatty, } \\
\text { aldehydic, grass, leafy, } \\
\text { fruity, sweaty, tallow } \\
{[3,11,49]}\end{array}$ \\
\hline 5.10 & Furfural & $54.37^{\mathrm{a}, \mathrm{b}} \pm 1.28$ & $16.73^{b} \pm 4.00$ & $31.98^{b} \pm 0.60$ & $94.66^{a} \pm 21.16$ & $\begin{array}{l}\text { Burnt, sweet, woody, } \\
\text { almond, bread, } \\
\text { rancid [3] }\end{array}$ \\
\hline
\end{tabular}


Table 5. Cont.

\begin{tabular}{|c|c|c|c|c|c|c|}
\hline $\begin{array}{l}\text { Retention } \\
\text { Index (min.) }\end{array}$ & Compound & S1 Bread & S2 Bread & S3 Bread & S4 Bread & Odor Descriptors \\
\hline 6.70 & Heptanal & $8.76^{b} \pm 0.48$ & $7.59^{b} \pm 3.29$ & $15.74^{\mathrm{a}, \mathrm{b}} \pm 1.21$ & $20.34^{a} \pm 1.96$ & $\begin{array}{l}\text { Green, rancid, } \\
\text { aldehydic, fatty, } \\
\text { grass [3] }\end{array}$ \\
\hline 8.17 & Benzaldehyde & $11.62^{a, b} \pm 0.31$ & $9.64^{b} \pm 0.87$ & $15.40^{\mathrm{a}} \pm 1.54$ & $15.70^{a} \pm 2.04$ & $\begin{array}{l}\text { Almond, sweet, } \\
\text { cherry }[3,51]\end{array}$ \\
\hline 9.27 & Octanal & $<4.00$ & $<4.00$ & $<4.00$ & $11.27^{a} \pm 0.94$ & Citrus-like, green [56] \\
\hline 10.33 & Benzeneacetaldehyde & $23.92^{a} \pm 0.54$ & $12.20^{b} \pm 1.19$ & $26.75^{a} \pm 2.41$ & $29.10^{a} \pm 2.53$ & Honey-like [3] \\
\hline \multirow[t]{2}{*}{11.87} & Nonanal & $13.36^{\mathrm{b}} \pm 1.86$ & $31.17^{\mathrm{a}} \pm 4.61$ & $23.53^{\mathrm{a}, \mathrm{b}} \pm 1.04$ & $27.35^{\mathrm{a}, \mathrm{b}} \pm 6.04$ & $\begin{array}{c}\text { Soapy, fruit, rose, } \\
\text { citrus, orange }[3,47]\end{array}$ \\
\hline & Ketones & $\mathrm{nf}$ & $9.82^{\mathrm{a}} \pm 0.79$ & $\mathrm{nf}$ & $8.43^{a} \pm 0.62$ & \\
\hline 2.77 & 2,3-Pentadione & $<5.00$ & $<5.00$ & $<5.00$ & $8.43^{a} \pm 0.62$ & \\
\hline \multirow[t]{2}{*}{8.88} & $\begin{array}{l}\text { 6-Methyl-5- } \\
\text { hepten-2one }\end{array}$ & $<5.00$ & $9.82^{a} \pm 0.79$ & $<5.00$ & $<5.00$ & \\
\hline & Organic acids & $171.57^{\mathrm{a}} \pm 17.17$ & $91.40^{b} \pm 6.38$ & $173.81^{\mathrm{a}} \pm 1.18$ & $143.04^{a} \pm 13.34$ & \\
\hline \multirow[t]{2}{*}{1.94} & Acetic acid & $171.57^{a} \pm 17.17$ & $91.40^{b} \pm 6.38$ & $173.81^{\mathrm{a}} \pm 1.18$ & $143.04^{a} \pm 13.34$ & $\begin{array}{l}\text { Sharp, Acrid, Vinegar, } \\
\text { Sour }[11,47]\end{array}$ \\
\hline & $\begin{array}{l}\text { Heterocyclic } \\
\text { compounds }\end{array}$ & $56.28^{\mathrm{b}} \pm 1.69$ & $39.74^{c} \pm 1.10$ & $57.88^{\mathrm{b}} \pm 6.10$ & $79.09^{\mathrm{a}} \pm 2.81$ & \\
\hline 8.98 & 2-Pentylfuran & $53.30^{\mathrm{b}} \pm 1.65$ & $31.95^{c} \pm 1.09$ & $52.90^{\mathrm{b}} \pm 8.39$ & $72.49^{a} \pm 3.01$ & $\begin{array}{l}\text { Fruity, green, earthy, } \\
\text { bean, metallic }[2,3]\end{array}$ \\
\hline \multirow[t]{2}{*}{13.26} & 2,3-Dihydrofuran & $2.98^{c} \pm 0.38$ & $7.79^{a} \pm 0.71$ & $4.98^{b} \pm 0.15$ & $6.60^{\mathrm{a}, \mathrm{b}} \pm 0.53$ & \\
\hline & Alkanes & $43.35^{b} \pm 3.10$ & $31.68^{d} \pm 2.10$ & $67.03^{a} \pm 2.14$ & $38.88^{c} \pm 1.44$ & \\
\hline 2.00 & Hexane & $<4.00$ & $9.81^{\mathrm{a}} \pm 1.98$ & $9.07^{\mathrm{a}} \pm 1.36$ & $<4.00$ & \\
\hline 3.57 & $\begin{array}{c}\text { 2,3- } \\
\text { Dimethylhexane }\end{array}$ & $<5.00$ & $9.21^{\mathrm{a}} \pm 0.02$ & $<5.00$ & $<5.00$ & \\
\hline 3.78 & Isoctane & $13.90^{\mathrm{a}} \pm 3.44$ & $6.01^{\mathrm{a}} \pm 0.34$ & $12.41^{\mathrm{a}} \pm 1.19$ & $13.35^{\mathrm{a}} \pm 1.70$ & \\
\hline 4.04 & $\begin{array}{c}2,2,5- \\
\text { Trimethylhexane }\end{array}$ & $9.02^{b} \pm 0.93$ & $<4.00$ & $16.42^{\mathrm{a}} \pm 2.09$ & $18.83^{a} \pm 0.16$ & \\
\hline 7.40 & 2-Nonane & $20.43^{a} \pm 3.69$ & $6.65^{b} \pm 0.66$ & $16.60^{\mathrm{a}} \pm 1.47$ & $<3.00$ & \\
\hline \multirow[t]{2}{*}{9.53} & $\begin{array}{c}2,5,5- \\
\text { Trimethylheptane }\end{array}$ & $<3.00$ & $<3.00$ & $12.53^{a} \pm 0.89$ & $6.70^{b} \pm 0.04$ & \\
\hline & Others & $112.99^{a} \pm 3.38$ & $57.23^{c} \pm 1.44$ & $121.37^{\mathrm{a}} \pm 3.44$ & $72.55^{b} \pm 3.32$ & \\
\hline 5.26 & $\begin{array}{c}2,4- \\
\text { Dimethylheptene }\end{array}$ & $75.34^{\mathrm{a}} \pm 4.82$ & $27.96^{\mathrm{b}} \pm 6.02$ & $61.37^{\mathrm{a}} \pm 0.85$ & $42.10^{\mathrm{b}} \pm 4.20$ & \\
\hline 6.48 & p-Xylene & $<5.00$ & $<5.00$ & $12.92 \pm 0.54$ & $<5.00$ & \\
\hline 10.70 & $\begin{array}{l}\text { 4,4-Dimethyl-1- } \\
\text { pentene }\end{array}$ & $3.84^{b} \pm 0.22$ & $4.76^{\mathrm{a}} \pm 0.17$ & $2.68^{c} \pm 0.25$ & $3.46^{b, c} \pm 0.15$ & \\
\hline 11.25 & 3-Ethyl-4-nonene & $11.16^{a} \pm 1.78$ & $4.79^{b} \pm 0.43$ & $7.89^{a, b} \pm 0.57$ & $6.68^{b} \pm 0.18$ & \\
\hline 15.56 & $\begin{array}{c}\text { m-Di-tert- } \\
\text { butylbenzene }\end{array}$ & $22.65^{b} \pm 3.31$ & $19.72^{b} \pm 2.89$ & $36.51^{\mathrm{a}} \pm 3.71$ & $20.31^{b} \pm 1.16$ & \\
\hline
\end{tabular}




\section{Biplot (F1 and F2: 95.59\%)}

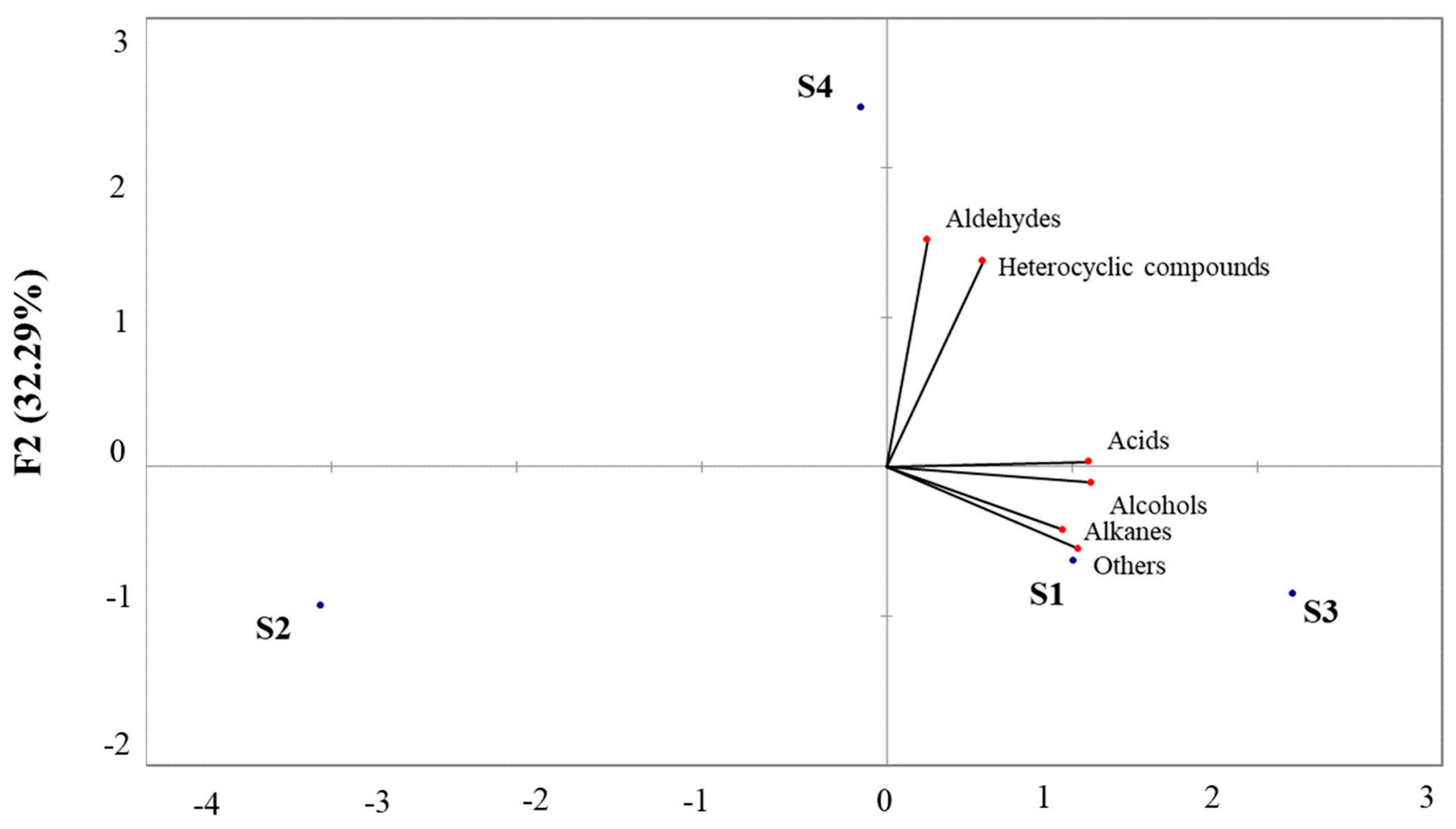

Figure 2. Principal component analysis (PCA) of volatile organic compounds (VOCs) in bread obtained from different sourdoughs (S1, S2, S3, and S4).

\section{Conclusions}

Different bacteria/yeast ratios in sourdoughs used to produce bread determine different contents of total organic acids (lactic, acetic, succinic, and citric acid) ranging from 7247.18 to $14,739.71 \mathrm{mg} / \mathrm{kg}$ in bread with yeast beer and bread prepared with a 1.5 ratio bacteria/yeast, respectively. The sourdough with a 1.5 ratio of bacteria/yeast showed the highest quotient of fermentation of 3.41, which is characteristic of lactic fermentation, and it has to be considered the best leaven. The quotient of fermentation affects the aroma profile and is also relevant for the structure of final products. The bread sample made from sourdough with a 1.5 ratio of bacteria/yeast had the highest value of lactic acid $(8722.24 \mathrm{mg} / \mathrm{kg})$, which is correlated to a more elastic gluten structure.

Regarding the volatile organic compounds, this bread sample had a considerable amount of total alcohols (367.33 ng/g) and acetic acid (171.57 ng/g).

Alcohols, acids, and aldehydes represent the most characteristic volatile compound families influencing the odors of fruity, green, floral, sweet, alcoholic, and fatty acids in bread.

Author Contributions: Conceptualization, R.R.; methodology, A.A. and L.D.L.; validation, R.R., F.P. and G.B.; formal analysis, L.D.L.; data curation, A.A. and L.D.L.; writing-original draft preparation, L.D.L.; writing - review and editing, F.P.; visualization, M.A.; supervision, R.R. and F.P.; funding acquisition, R.R. All authors have read and agreed to the published version of the manuscript.

Funding: This research was funded by PON Sweet Campania (finanziamento MISE circolare 5067 del 13/02/2014).

Institutional Review Board Statement: Not applicable.

Informed Consent Statement: Not applicable. 
Data Availability Statement: Research data are not shared.

Acknowledgments: The authors wish to thank San Giorgio Spa in Castel Sangiorgio (SA) Italy, Foodtech srl (Alessandro Acunzo) and Beta srl in Salerno Italy for research support and Giorgio Cozzolino from the Department of Agricultural Sciences, University of Naples Federico II, for his informatic support.

Conflicts of Interest: The authors declare no conflict of interest.

\section{References}

1. Spicher, G.; Stephen, H.S. Handbuch Sauerteig: Biologie, Biochemie, Technologie; B. Behr's Verlag GmbH: Hamburg, Germany, 1993.

2. Chavan, R.S.; Chavan, S.R. Sourdough technology-A traditional way for wholesome foods: A review. Compr. Rev. Food Sci. Saf. 2011, 10, 169-182. [CrossRef]

3. Pétel, C.; Onno, B.; Prost, C. Sourdough volatile compounds and their contribution to bread: A review. Trends Food Sci. Technol. 2017, 59, 105-123. [CrossRef]

4. Gobbetti, M.; Rizzello, C.G.; Di Cagno, R.; De Angelis, M. How the sourdough may affect the functional features of leavened baked goods. Food Microbiol. 2014, 37, 30-40. [CrossRef] [PubMed]

5. Gänzle, M.G. Enzymatic and bacterial conversions during sourdough fermentation. Food Microbiol. 2014, 37, 2-10. [CrossRef] [PubMed]

6. Van Kerrebroeck, S.; Bastos, F.C.C.; Harth, H.; De Vuyst, L. A low pH does not determine the community dynamics of spontaneously developed backslopped liquid wheat sourdoughs but does influence their metabolite kinetics. Int. J. Food Microbiol. 2016, 239, 54-64. [CrossRef] [PubMed]

7. De Vuyst, L.; Van Kerrebroeck, S.; Harth, H.; Huys, G.; Daniel, H.M.; Weckx, S. Microbial ecology of sourdough fermentations: Diverse or uniform? Food Microbiol. 2014, 37, 11-29. [CrossRef] [PubMed]

8. Hansen, A.; Schieberle, P. Generation of aroma compounds during sourdough fermentation: Applied and fundamental aspects. Trends Food Sci. Technol. 2005, 16, 85-94. [CrossRef]

9. Hansen, A.; Lund, B.; Lewis, M.J. Flavour of sourdough rye bread crumb. Lebensm. Wiss. Technol. 1989, $22,141$.

10. Cho, I.H.; Peterson, D.G. Chemistry of bread aroma: A review. Food Sci. Biotechnol. 2010, 19, 575-582. [CrossRef]

11. Pico, J.; Bernal, J.; Gómez, M. Wheat bread aroma compounds in crumb and crust: A review. Food Res. Int. 2015, 75, 200-215. [CrossRef]

12. Damiani, P.; Gobbetti, M.; Cossignani, L.; Corsetti, A.; Simonetti, M.S.; Rossi, J. The sourdough microflora. Characterization of hetero-and homofermentative lactic acid bacteria, yeasts and their interactions on the basis of the volatile compounds produced. LWT Food Sci. Technol. 1996, 29, 63-70. [CrossRef]

13. Seitz, L.M.; Chung, O.K.; Rengarajan, R. Volatiles in selected commercial breads. Cereal Chem. 1998, 75, 847-853. [CrossRef]

14. Gobbetti, M.; De Angelis, M.; Di Cagno, R.; Calasso, M.; Archetti, G.; Rizzello, C.G. Novel insights on the functional/nutritional features of the sourdough fermentation. Int. J. Food Microbiol. 2019, 302, 103-113. [CrossRef] [PubMed]

15. Crowley, P.; Schober, T.J.; Clarke, C.I.; Arendt, E.K. The effect of storage time on textural and crumb grain characteristics of sourdough wheat bread. Eur. Food Res. Technol. 2002, 214, 489-496. [CrossRef]

16. Park, Y.H.; Jung, L.H.; Jeon, E.R. Quality characteristics of bread using sour dough. J. Food Sci. Nutr. 2006, 11, 323-327. [CrossRef]

17. G.U 189/1967. Disciplina per la Lavorazione e Commercio dei Cereali, degli Sfarinati, del Pane e Delle Paste Alimentari (Legge 4 luglio 1967, n. 580) Gazzetta Ufficiale Italiana n.189 del 29-07-1967 Serie Generale. Available online: https://www. gazzettaufficiale.it/eli/id/1967/07/29/067U0580/sg (accessed on 27 December 2020).

18. Mueen-ud-Din, G.; Anjum, F.M.; Rehman, S.U.; Nawaz, H. Studies on organic acids and minerals content of sourdough naans made from different extraction rate wheat flours and starter cultures. Pak. J. Nutr. 2009, 8, 877-881. [CrossRef]

19. Ua-Arak, T.; Jacob, F.; Vogel, R.F. Characterization of growth and exopolysaccharides production of selected acetic acid bacteria in buckweath sourdough. Int. J. Food Microbiol. 2016, 239, 103-112. [CrossRef]

20. Aponte, M.; Boscaino, F.; Sorrentino, A.; Coppola, R.; Masi, P.; Romano, A. Volatile compounds and bacterial community dynamics of chestnut-flour-based sourdoughs. Food Chem. 2013, 141, 2394-2404. [CrossRef]

21. Gobbetti, M.; Minervini, F.; Pontonio, E.; Di Cagno, R.; De Angelis, M. Drivers for the establishment and composition of the sourdough lactic acid bacteria biota. Int. J. Food Microbiol. 2016, 239, 3-18. [CrossRef]

22. Torrieri, E.; Pepe, O.; Ventorino, V.; Masi, P.; Cavella, S. Effect of sourdoygh at different concentration on quality and shelf-life of bread. LWT Food Sci. Technol. 2014, 56, 508-516. [CrossRef]

23. Scazzina, F.; Del Rio, D.; Pellegrini, N.; Brighenti, F. Sourdough bread: Starch digestibility and postprandial glycemic response. J. Cereal Sci. 2009, 49, 419-421. [CrossRef]

24. Zolfaghari, M.S.; Asadi, G.; Ardebili, S.M.S.; Larijani, K. Evaluation and comparison of different dough leavening agents on quality of lavash bread. J. Food Meas. Charact. 2017, 11, 93-98. [CrossRef]

25. Mohd Roby, B.H.; Muhialdin, B.J.; Abadl, M.M.T.; Mat Nor, N.A.; Marzlan, A.A.; Lim, S.A.H.; Mustapha, N.A.; Meor Hussin, A.S. Physical properties, storage stability, and consumer acceptability for sourdough bread produced using encapsulated kombucha sourdough starter culture. J. Food Sci. 2020, 85, 2286-2295. [CrossRef] [PubMed] 
26. Ho, L.H.; Abdul Aziz, N.A.; Bhat, R.; Azahari, B. Storage studies of bread prepared by incorporation of the banana pseudo-stem flour and the composite breads containing hydrocolloids. CyTA J. Food 2014, 12, 141-149. [CrossRef]

27. Markova, N.; Wadsö, L. A microcalorimetric method of studying mould activity as a function of water activity. Int. Biodeter Biodegr. 1998, 42, 25-28. [CrossRef]

28. Gobbetti, M.; Simonetti, M.S.; Corsetti, A.; Santinelli, F.; Rossi, J.; Damiani, P. Volatile compound and organic acid productions by mixed wheat sour dough starters: Influence of fermentation parameters and dynamics during baking. Food Microbiol. 1995, 12, 497-507. [CrossRef]

29. De Vuyst, L.; Neysens, P. The sourdough microflora: Biodiversity and metabolic interactions. Trends Food Sci. Technol. 2005, 16, 43-56. [CrossRef]

30. Barber, B.; Ortolá, C.; Barber, S.; Fernandez, F. Storage of packaged white bread. Z. Lebensm. Unters. For. 1992, 194, 442-449. [CrossRef]

31. Lim, S.B.; Tingirikari, J.M.R.; Seo, J.S.; Li, L.; Shim, S.; Seo, J.H.S. Isolation of lactic acid bacteria starters from Jeung-pyun for sourdough fermentation. Food Sci. Biotechnol. 2018, 27, 73-78. [CrossRef]

32. Mamhoud, A.; Nionelli, L.; Bouzaine, T.; Hamdi, M.; Gobbetti, M.; Rizzello, C.G. Selection of lactic acid bacteria isolated from Tunisian cereals and exploitation of the use as starters for sourdough fermentation. Int. J. Food Microbiol. 2016, 225, 9-19. [CrossRef]

33. Spicher, G.; Stephan, H. Handbuch Sauerteig, Biologie, Biochemie, Technologie, 5th ed.; Behr's Verlag: Hamburg, Germany, 1999.

34. Corsetti, A. Technology of sourdough fermentation and sourdough applications. In Handbook on Sourdough Biotechnology; Springer: Boston, MA, USA, 2013; pp. 85-103.

35. Corsetti, A.; Gobbetti, M.; De Marco, B.; Balestrieri, F.; Paoletti, F.; Russi, L.; Rossi, J. Combined effect of sourdough lactic acid bacteria and additives on bread firmness and staling. J. Agric. Food Chem. 2000, 48, 3044-3051. [CrossRef] [PubMed]

36. Casal, M.; Cardoso, H.; Leão, C. Effects of ethanol and other alkanols on transport of acetic acid in Saccharomyces cerevisiae. Appl. Environ. Microb. 1998, 64, 665-668. [CrossRef] [PubMed]

37. Casal, M.; Cardoso, H.; Leao, C. Mechanisms regulating the transport of acetic acid in Saccharomyces cerevisiae. Microbiology 1996, 142, 1385-1390. [CrossRef]

38. Hadaegh, H.; Seyyedain Ardabili, S.M.; Tajabadi Ebrahimi, M.; Chamani, M.; Azizi Nezhad, R. The impact of different lactic acid bacteria sourdoughs on the quality characteristics of toast bread. J. Food Qual. 2017, 2017, 1-11. [CrossRef]

39. Gobbetti, M. The sourdough microflora: Interactions of lactic acid bacteria and yeasts. Trends Food Sci. Technol. 1998, 9, 267-274. [CrossRef]

40. Arendt, E.K.; Ryan, L.A.; Dal Bello, F. Impact of sourdough on the texture of bread. Food Microbiol. 2007, 24, 165-174. [CrossRef]

41. Plessas, S.; Bekatorou, A.; Gallanagh, J.; Nigam, P.; Koutinas, A.A.; Psarianos, C. Evolution of aroma volatiles during storage of sourdough breads made by mixed cultures of Kluyveromyces marxianus and Lactobacillus delbrueckii ssp. bulgaricus or Lactobacillus helveticus. Food Chem. 2008, 107, 883-889.

42. Kaseleht, K.; Paalme, T.; Mihhalevski, A.; Sarand, I. Analysis of volatile compounds produced by different species of lactobacilli in rye sourdough using multiple headspace extraction. Int. J. Food Sci. Technol. 2011, 46, 1940-1946. [CrossRef]

43. Birch, A.N.; Petersen, M.A.; Arneborg, N.; Hansen, Å.S. Influence of commercial baker's yeasts on bread aroma profiles. Food Res. Int. 2013, 52, 160-166. [CrossRef]

44. Birch, A.N.; Petersen, M.A.; Hansen, Å.S. Aroma of wheat bread crumb. Cereal Chem. 2014, 91, 105-114. [CrossRef]

45. Annan, N.T.; Poll, L.; Sefa-Dedeh, S.; Plahar, W.A.; Jakobsen, M. Volatile compounds produced by Lactobacillus fermentum, Saccharomyces cerevisiae and Candida krusei in single starter culture fermentations of Ghanaian maize dough. J. Appl. Microbiol. 2003, 94, 462-474. [CrossRef] [PubMed]

46. Salin-ur-Rehman, P.A.; Piggott, J.R. Flavour in sourdough breads: A review. Food Sci. Technol. 2006, 17, 557-566. [CrossRef]

47. Pozo-Bayon, M.A.; Guichard, E.; Cayot, N. Flavor control in baked cereal products. Food Rev. Int. 2006, 22, 335-379. [CrossRef]

48. Birch, A.N.; Petersen, M.A.; Hansen, Å.S. The aroma profile of wheat bread crumb influenced by yeast concentration and fermentation temperature. LWT-Food Sci. Technol. 2013, 50, 480-488. [CrossRef]

49. Poinot, P.; Grua-Priol, J.; Arvisenet, G.; Rannou, C.; Semenou, M.; Le Bail, A.; Prost, C. Optimisation of HS-SPME to study representativeness of partially baked bread odorant extracts. Food Res. Int. 2007, 40, 1170-1184. [CrossRef]

50. Bianchi, F.; Careri, M.; Chiavaro, E.; Musci, M.; Vittadini, E. Gas chromatographic-mass spectrometric characterisation of the Italian protected designation of origin "Altamura" bread volatile profile. Food Chem. 2008, 110, 787-793. [CrossRef]

51. Paraskevopoulou, A.; Chrysanthou, A.; Koutidou, M. Characterisation of volatile compounds of lupin protein isolate-enriched wheat flour bread. Food Res. Int. 2012, 48, 568-577. [CrossRef]

52. Jensen, S.; Oestdal, H.; Skibsted, L.H.; Larsen, E.; Thybo, A.K. Chemical changes in wheat pan bread during storage and how it affects the sensory perception of aroma, flavour, and taste. J. Cereal Sci. 2011, 53, 259-268. [CrossRef]

53. Chiavaro, E.; Vittadini, E.; Musci, M.; Bianchi, F.; Curti, E. Shelf-life stability of artisanally and industrially produced durum wheat sourdough bread ("Altamura bread"). LWT Food Sci. Technol. 2008, 41, 58-70. [CrossRef]

54. Hansen, Å.; Hansen, B. Flavour of sourdough wheat bread crumb. Z. Lebensm. Unters. For. 1996, 202, 244-249. [CrossRef]

55. Adams, A.; Bouckaert, C.; Van Lancker, F.; De Meulenaer, B.; De Kimpe, N. Amino acid catalysis of 2-alkylfuran formation from lipid oxidation-derived $\alpha, \beta$-unsaturated aldehyde. J. Agric. Food Chem. 2011, 59, 11058-11062. [CrossRef] [PubMed] 
56. Czerny, M.; Christlbauer, M.; Christlbauer, M.; Fischer, A.; Granvogl, M.; Hammer, M.; Hartl, C.; Hernandez, N.M.; Schieberle, P. Re-investigation on odour thresholds of key food aroma compounds and development of an aroma language based on odour qualities of defined aqueous odorant solutions. Eur. Food Res. Technol. 2008, 228, 265-273. [CrossRef]

57. Park, H.J.; Lee, S.M.; Song, S.H.; Kim, Y.S. Characterization of volatile components in Makgeolli, a traditional Korean rice wine, with or without pasteurization, during storage. Molecules 2013, 18, 5317-5325. [CrossRef] [PubMed] 